\title{
Application of auxin-inducible degron technology to mouse oocyte activation with PLC $\zeta$
}

\author{
Kento MIURA ${ }^{1)}$, Shogo MATOBA ${ }^{1)}$, Narumi OGONUKI ${ }^{1)}$, Takafumi NAMIKI'), Junya ITO ${ }^{2)}$, \\ Naomi KASHIWAZAKI ${ }^{2)}$ and Atsuo OGURA ${ }^{1,3,4)}$ \\ 1) RIKEN BioResource Research Center, Ibaraki 305-0074, Japan \\ 2) Laboratory of Animal Reproduction, Graduate School of Veterinary Science, Azabu University, Kanagawa 252-5201, \\ Japan \\ 3) RIKEN Cluster for Pioneering Research, Saitama 351-0198, Japan \\ 4) Graduate School of Life and Environmental Sciences, University of Tsukuba, Ibaraki 305-8572, Japan
}

\begin{abstract}
In mammals, spermatozoa activate oocytes by triggering a series of intracellular $\mathrm{Ca}^{2+}$ oscillations with

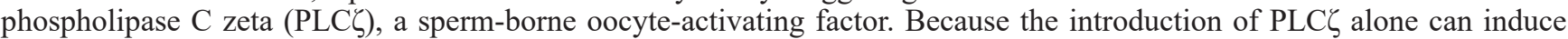
oocyte activation, it might be a promising reagent for assisted reproductive technologies. To test this possibility, we injected human PLC $\zeta$ (hPLC $\zeta$ ) mRNA into mouse oocytes at different concentrations. We observed the oocyte activation and subsequent embryonic development. Efficient oocyte activation and embryonic development to the blastocyst stage was achieved only with a limited range of mRNA concentrations $(0.1 \mathrm{ng} / \mu \mathrm{l})$. Higher concentrations of mRNA caused developmental arrest of most embryos, suggesting that excessive PLC $\zeta$ protein might be harmful at this stage. In a second series of experiments, we aimed to regulate the PLC $\zeta$ protein concentration in oocytes by applying auxin-inducible degron (AID) technology that allows rapid degradation of the target protein tagged with AID induced by auxin. Injection of the hPLC $\zeta$ protein tagged with AID and enhanced green fluorescent protein (hPLCל-AID-EGFP) demonstrated that high EGFP expression levels at the late 1 -cell stage were efficiently reduced by auxin treatment, suggesting efficient $h P L C \zeta$ degradation by this system. Furthermore, the defective development observed with higher concentrations of hPLCל-AID-EGFP mRNA was rescued following auxin treatment. Full-term offspring were obtained by round spermatid injection with optimized hPLC $\zeta$-AID activation. Our results indicate that this AID technology can be applied to regulate the protein levels in mouse oocytes and that our optimized PLC $\zeta$ system could be used for assisted fertilization in mammals.
\end{abstract}

Key words: Auxin-inducible degron technology, Mouse, Oocyte activation, Round spermatid injection, Sperm-specific phospholipase C zeta

(J. Reprod. Dev. 64: 319-326, 2018)

$\mathbf{T}$ he fertilization of oocytes by spermatozoa is the earliest event of the life cycle. Following fertilization, the oocyte initiates repetitive rises of intracellular $\mathrm{Ca}^{2+}$ concentration $\left(\mathrm{Ca}^{2+}\right.$ oscillations) and resumes its meiotic cell cycle to exit from metaphase II (MII). This dynamic event, which is called oocyte activation, is known to be crucial for subsequent proper embryonic development [1-3]. Because spermatogenic cells acquire their oocyte-activating capacity as they develop in the testes, earlier spermatogenic cells, such as round spermatids, have little or no such capacity, depending on the species. Therefore, when immature spermatogenic cells are used for fertilizing oocytes by microinjection, oocyte activation by artificial stimuli is necessary in many cases. In mice, for example, several methods have been used to activate oocytes, such as electric pulses or strontium chloride treatment [4-6].

Received: April 7, 2018

Accepted: April 18, 2018

Published online in J-STAGE: May 5, 2018

(C)2018 by the Society for Reproduction and Development

Correspondence: A Ogura (e-mail: ogura@rtc.riken.go.jp)

This is an open-access article distributed under the terms of the Creative Commons Attribution Non-Commercial No Derivatives (by-nc-nd) License. (CC-BY-NC-ND 4.0: https://creativecommons.org/licenses/by-nc-nd/4.0/)
In 2002, Saunders et al. [7] identified the novel sperm-specific phospholipase $\mathrm{C}$ zeta (PLC $\zeta$ ) as a candidate for a sperm-borne oocyte-activating factor that is capable of inducing $\mathrm{Ca}^{2+}$ oscillations [8]. Subsequent studies revealed that PLC $\zeta$ is conserved across mammalian species and mutations in the gene encoding PLC $\zeta$ are linked to human infertility [9-12]. Indeed, sperm extracts depleted of PLC $\zeta$ or sperm derived from $\mathrm{Plcz}^{-1-}$ male mice failed to trigger $\mathrm{Ca}^{2+}$ oscillations $[7,13,14]$. Importantly, the major structural basis for the function of PLC $\zeta$ seems to be common across mammalian species because PLC $\zeta$ mRNA from one species can induce the activation of oocytes of different species $[10,15]$. However, it is interesting to note that the potential of inducing $\mathrm{Ca}^{2+}$ oscillations and nuclear-cytoplasmic localization patterns of this factor appear to be species-dependent $[15,16]$. The absolute amount of PLC $\zeta$ protein has been suggested to be critical for the proper oocyte activation and embryonic development. A low amount of PLC $\zeta$ was unable to induce oocyte activation, whereas a high concentration of PLC $\zeta$ mRNA injection caused developmental arrest of embryos [17].

Auxin-inducible degron (AID) technology is an auxin-inducible protein degradation system that enables temporal control of protein stability [18]. In plants, auxin binds to the transport inhibitor response 1 (TIR1) protein and promotes binding of a functional Skp1-Cullin- 
F-box (SCF) ubiquitin ligase, which forms a complex with TIR, to target proteins harboring a small tag, called the AID tag [19, 20]. The targeted proteins are polyubiquitinated by SCF-TIR1 complexes and are quickly degraded by proteasomes. Nishimura et al. [18] converted the plant-specific AID system to a technology enabling auxin-dependent degradation of target proteins tagged with AID even in non-plant cells, including mammalian cells, contributing to the analysis of protein function [21].

Here, we applied AID technology to the degradation of the PLC $\zeta$ protein translated from mRNA injected into mouse oocytes and examined the effects of its degradation on embryonic development. We found that the AID technology could induce degradation of the targeted PLC $\zeta$ protein and that embryonic demise because of a high concentration of PLC $\zeta$ protein could be rescued by auxin-dependent PLC $\zeta$ degradation.

\section{Materials and Methods}

\section{Animals}

B6D2F1 $(\mathrm{C} 57 \mathrm{BL} / 6 \mathrm{~N} \times \mathrm{DBA} / 2)$ strain mice were obtained from Japan SLC (Hamamatsu, Japan) and C57BL/6J and ICR strain mice were obtained from CLEA Japan (Tokyo, Japan) at 8-10 weeks of age. They were housed with food and water ad libitum under controlled temperature $\left(24 \pm 1^{\circ} \mathrm{C}\right)$, humidity $(55 \pm 2 \%)$, and lighting conditions (daily light period, 0700 to $2100 \mathrm{~h}$ ). The animal experiments described here were approved by the Animal Experimentation Committee at the RIKEN Tsukuba Institute, and were performed in accordance with the committee's guiding principles.

\section{Media}

Potassium-modified simplex optimized medium (KSOM) [22] was used for embryo culture in a humidified atmosphere of $5 \%$ $\mathrm{CO}_{2}$ in air at $37^{\circ} \mathrm{C}$. HEPES-buffered KSOM was used for gamete handling and round spermatid injection (ROSI) at room temperature. $\mathrm{Ca}^{2+}$-free KSOM containing $3 \mathrm{mM}$ strontium chloride was used for activating oocytes without using human PLC $\zeta$ (hPLC $\zeta$ ) injection as a positive control.

\section{Oocyte collection}

Female B6D2F1 mice were induced to superovulate by an injection of 7.5 IU equine chorionic gonadotropin (Nippon Zenyaku Kogyo, Fukushima, Japan), followed $48 \mathrm{~h}$ later by $7.5 \mathrm{IU}$ of human chorionic gonadotropin (hCG) (ASKA Pharmaceutical, Tokyo, Japan). At 16 $\mathrm{h}$ after injecting hCG, cumulus-oocyte complexes were collected from the oviducts and placed in a KSOM droplet containing $0.1 \%$ bovine testicular hyaluronidase (\#385931; Calbiochem, La Jolla, CA, USA) for $3 \mathrm{~min}$. The cumulus-free oocytes were washed five times and cultured in fresh KSOM until use.

\section{Plasmid construction and in vitro transcription for human PLCᄃ mRNA synthesis}

We amplified a cDNA sequence encoding hPLC $\zeta[10,15]$ and subcloned it into pcDNA3.1-p(A)83 vectors [23]. According to previous reports, $\mathrm{hPLC} \zeta$ had a stronger $\mathrm{Ca}^{2+}$ oscillation-inducing potential than mouse PLC $\zeta[10,15,17]$. In the present study, therefore, we used hPLC $\zeta$ mRNA, expecting that the smaller amount of the PLC $\zeta$ protein required for oocyte activation would cause rapid elimination of PLC $\zeta$ from auxin-treated oocytes. OsTIR1 (TIR1 derived from Oryza sativa) and an AID fragment [1-132 amino acids (aa) of the 1-229 aa full-length AID] [24, 25] from OsTIR1-9Myc::IRES::aidCENPH (pMK106; RDB08469; RIKEN BioResource Center, Tsukuba, Japan) [18] were also ligated to pcDNA3.1-p(A)83 vectors. These pcDNA3.1-p(A)83 vectors and pcDNA3.1-EGFP-p(A)83 [23] were used as template plasmids for in vitro transcription. To generate the template plasmid of a fused hPLC $\zeta$-AID-EGFP mRNA, DNA fragments of $\mathrm{hPLC} \zeta, \mathrm{AID}$, and EGFP were amplified by polymerase chain reaction (PCR) from the linearized template plasmids and cloned into a pcDNA3.1-poly(A)83 plasmid by using a Gibson Assembly Cloning Kit (\# E5510; New England BioLabs, Beverly, MA, USA). RNA was synthesized from the linearized template plasmids by in vitro transcription using a mMESSAGE mMACHINE T7 Ultra Kit (Life Technologies \# AM1345; Thermo Fisher Scientific, Waltham, MA, USA) following the manufacturer's instructions. The synthesized mRNAs were precipitated by lithium chloride and dissolved in nuclease-free water. After measuring the concentration using a NanoDrop ND-1000 spectrophotometer (NanoDrop Technologies, Wilmington, DE, USA), aliquots were stored at $-80^{\circ} \mathrm{C}$ until use.

\section{$m R N A$ injection}

Microinjection of mRNA was carried out using a Piezo-driven micropipette (Prime Tech, Ibaraki, Japan). Several droplets ( 4 $\mu \mathrm{l})$ of HEPES-buffered KSOM with or without $10 \%$ polyvinylpyrrolidone (PVP) were placed on the bottom of the microinjection chamber and covered with mineral oil. The PVP-containing droplets were used for washing the tip of the micropipette for mRNA injection. We applied Piezo pulses to break the zona pellucida and oolemma [4]. Intact hPLC $\zeta$ or fused hPLC $\zeta$-AID-EGFP mRNA $\left(10^{-4}-10^{2} \mathrm{ng} / \mu \mathrm{l}\right)$ together with OsTIR1 mRNA $(1000 \mathrm{ng} / \mu \mathrm{l})$ were injected into oocytes in HEPES-buffered KSOM. Each oocyte received 10 pl mRNA. After mRNA injection, the oocytes were kept in HEPES-buffered $\mathrm{KSOM}$ at room temperature $\left(24^{\circ} \mathrm{C}\right)$ for $10 \mathrm{~min}$. Degradation of the hPLC $\zeta$-AID-EGFP protein was induced by $500 \mu \mathrm{M}$ indole-3-acetic acid (IAA, I5148; Sigma-Aldrich, St Louis, MO, USA), a natural auxin. The mRNA-injected oocytes were placed in fresh KSOM with or without IAA and cultured for $96 \mathrm{~h}$ at $37^{\circ} \mathrm{C}$ under $5 \% \mathrm{CO}_{2}$ in air. The oocytes activated for observation of parthenogenetic development were diploidized by adding $5 \mu \mathrm{g} / \mathrm{ml}$ cytochalasin B (CCB; \#250223; Calbiochem) to the culture medium for $0.5-6.5 \mathrm{~h}$ after mRNA injection. Control parthenogenetically activated embryos were generated by culturing oocytes in activation medium containing $5 \mu \mathrm{g} / \mathrm{ml} \mathrm{CCB}$ for $1 \mathrm{~h}$ followed by KSOM containing $5 \mu \mathrm{g} / \mathrm{ml} \mathrm{CCB}$ for $5 \mathrm{~h}$. After washing, they were further cultured in KSOM for 90 $\mathrm{h}$ as described above.

\section{Fluorescence microscopy}

To examine the levels of EGFP expression, fluorescent images were acquired using an inverted fluorescence microscope (IX70; Olympus, Tokyo, Japan). Oocytes or embryos were transferred to HEPES-buffered KSOM with or without IAA in a glass-bottomed dish on a thermo plate (Tokai Hit, Shizuoka, Japan) on the microscope stage. Fluorescence intensity was measured using ImageJ software (https://imagej.nih.gov/ij/download.html). 


\section{Round spermatid injection}

Spermatogenic cells were isolated mechanically from the seminiferous tubules of C57BL/6J males as previously described [26]. Cell suspensions were placed in a PVP droplet prepared on the manipulation chamber as described above. B6D2F1 oocytes were injected with $10^{\circ} \mathrm{ng} / \mu \mathrm{l} \mathrm{hPLC} \zeta$-AID-EGFP and $1000 \mathrm{ng} / \mu \mathrm{l}$ OsTIR1 mRNAs and cultured in KSOM containing IAA. At 3-5 h later, oocytes proceeded to telophase II with protrusion of the second polar body. They were then injected with round spermatids in HEPESbuffered KSOM containing IAA. The injected oocytes were kept in HEPES-buffered KSOM with IAA at room temperature $\left(24^{\circ} \mathrm{C}\right)$ for 10 min before reincubation in $\mathrm{KSOM}$ with IAA at $37^{\circ} \mathrm{C}$ under $5 \%$ $\mathrm{CO}_{2}$ in humidified air.

\section{Embryo transfer}

Two-cell embryos produced by ROSI were transferred into the oviducts of day 1 pseudopregnant females of ICR strain, which had been mated with a vasectomized male the night before transfer. For anesthesia, $2.5 \%$ tribromoethanol $(0.014 \mathrm{ml} / \mathrm{g}$ of body weight $)$ was administered by intraperitoneal injection. In the evening on days 18 and 19, each female mouse was injected subcutaneously with $2 \mathrm{mg}$ of progesterone to avert spontaneous delivery. On the morning of day 20 , the recipient mice were examined for the numbers of implantation sites, and live offspring were retrieved by Caesarean section.

\section{Statistical analysis}

Fisher's exact test, followed by Benjamini-Hochberg procedure [27] for multiple comparison tests, was performed for statistical analysis in Figs 1 and 2. Statistical significance was assessed at $P<$ 0.05. Quantitative data in Fig. $3 \mathrm{C}$ are shown as the mean \pm standard error of the mean.

\section{Results}

Injection of hPLCᄃ $m R N A$ into mouse oocytes induces activation and embryonic development in a dose-dependent manner

First, to examine the dose-dependent effect of hPLC $\zeta$ mRNA on oocyte activation and embryonic development, we microinjected different concentrations of $\mathrm{hPLC} \zeta \mathrm{mRNA}\left(10^{-4}-10^{2} \mathrm{ng} / \mu \mathrm{l}\right)$ into mouse MII oocytes (Fig. 1A). Oocyte activation was determined by pronuclear $(\mathrm{PN})$ formation at $6.5 \mathrm{~h}$ after mRNA injection. Injection of low concentrations of hPLC $\zeta$ mRNA $\left(10^{-4}-10^{-2} \mathrm{ng} /\right.$ $\mu \mathrm{l}$ ) induced activation in only $0-10 \%$ of the oocytes injected (Fig. 1B). Consequently, these oocytes showed very low 2-cell (8-13\%) and blastocyst (5-13\%) formation rates per injected oocytes (Fig. $1 \mathrm{C}, \mathrm{D})$. In the $10^{-2} \mathrm{ng} / \mu \mathrm{l}$ group, the 2-cell rate was higher than the activation rate, probably reflecting delayed activation of oocytes by a low concentration of PLC $\zeta$ mRNA, as previously reported [15]. In contrast, $92-100 \%$ of oocytes were activated after the injection of $10^{-1}-10^{2} \mathrm{ng} / \mu \mathrm{l} \mathrm{hPLC} \zeta \mathrm{mRNA}$, consistent with a previous report [17]. Among them, those injected with moderate concentrations of mRNA $\left(10^{-1}\right.$ and $\left.10^{0} \mathrm{ng} / \mu \mathrm{l}\right)$ showed the highest 2-cell and blastocyst formation rates in all the experimental groups. However, most $(87-100 \%)$ of the oocytes injected with higher concentrations of mRNA $\left(10^{1}\right.$ and $\left.10^{2} \mathrm{ng} / \mu \mathrm{l}\right)$ showed arrested development at the 1-cell
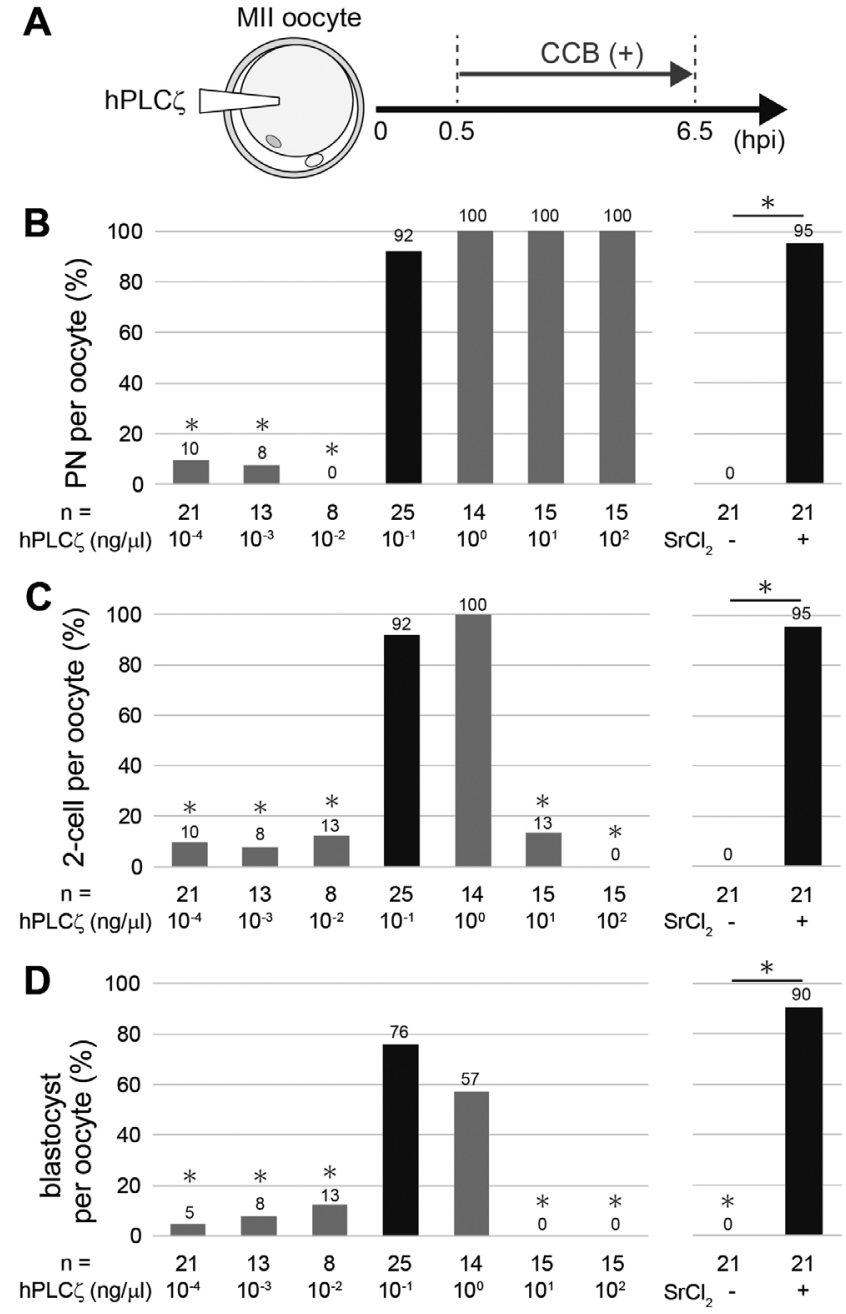

Fig. 1. Activation and development rates of mouse oocytes injected with hPLC $\zeta$ mRNA. A) Schematic representation of intact hPLC $\zeta$ mRNA injection into metaphase II (MII) stage mouse oocytes and their culture with CCB from $0.5-6.5 \mathrm{~h}$ post mRNA injection (hpi) to induce parthenogenesis. B-D) Rates of 2-pronuclei (PN; 6.5 hpi), 2-cell (24 hpi), and blastocyst (96 hpi) formation per oocytes that survived at $6.5 \mathrm{hpi}$. The oocytes were injected with $10^{-4}-10^{2}$ ng/ $\mu 1 \mathrm{hPLC} \zeta$ mRNA. * P $<0.05$, vs. $10^{-1} \mathrm{ng} / \mu$ l group. Key: $\mathrm{SrCl}_{2}$ $(-)$, oocytes without any activation treatment; $\mathrm{SrCl}_{2}(+)$, oocytes activated with strontium chloride. $* \mathrm{P}<0.05$.

stage even though they underwent $100 \%$ activation. These results indicated that, although injection of $\mathrm{hPLC} \zeta$ mRNA can efficiently induce activation of mouse oocytes at concentrations of $10^{-1} \mathrm{ng} / \mu \mathrm{l}$ or higher, an excessive amount of the hPLC $\zeta$ protein compromises subsequent embryonic development.

\section{Effect of fused $h P L C \zeta-A I D-E G F P$ mRNA injection without auxin}

To evaluate whether the fusion of AID and EGFP tags to the hPLC $\zeta$ protein or injection of an additional factor, OsTIR1, would affect the activation property of $\mathrm{hPLC} \zeta$, we performed a series of 

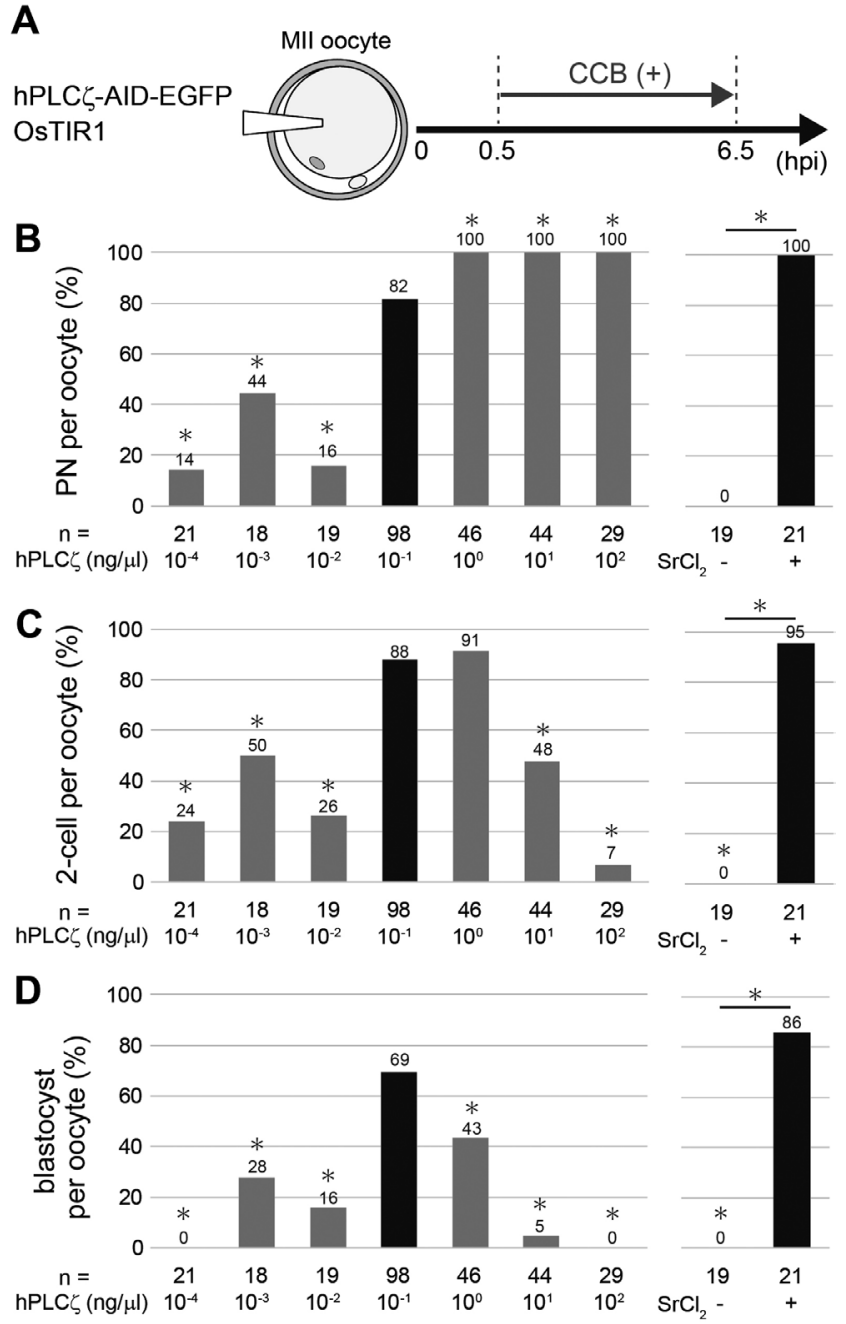

Fig. 2. Activation and development rates of mouse oocytes injected with fused hPLC $\zeta$-AID-EGFP mRNA. A) Schematic representation of hPLC -AID-EGFP and OsTIR1 mRNA injections into MII oocytes and their culture with CCB from $0.5-6.5 \mathrm{hpi}$ for inducing parthenogenesis. B-D) Rates of 2-PN formation (6.5 hpi), 2-cell (24 hpi), and blastocyst (96 hpi) development per oocytes that survived at $6.5 \mathrm{hpi}$. Oocytes were injected with $10^{-4}-10^{2} \mathrm{ng} /$ $\mu \mathrm{hPLC} \zeta$-AID-EGFP and $1000 \mathrm{ng} / \mu \mathrm{l}$ OsTIR1 mRNAs. ${ }^{*} \mathrm{P}<$ 0.05 , vs. $10^{-1} \mathrm{ng} / \mu 1$ group. Key: $\mathrm{SrCl}_{2}(-)$, oocytes without any activation treatment; $\mathrm{SrCl}_{2}(+)$, oocytes activated with strontium chloride. ${ }^{*} \mathrm{P}<0.05$.

injection experiments without auxin treatment. Injections of different concentrations of hPLC $\zeta$-AID-EGFP $\left(10^{-4}-10^{2} \mathrm{ng} / \mu \mathrm{l}\right)$ together with OsTIR1 $(1000 \mathrm{ng} / \mu \mathrm{l})$ mRNAs into mouse MII oocytes resulted in activation and embryonic development in the patterns nearly identical to those with intact hPLC $\zeta$ alone (Fig. 2). Specifically, the activation efficiency and subsequent developmental rate remained low by injection of $10^{-4}-10^{-2} \mathrm{ng} / \mu \mathrm{l} \mathrm{hPLC} \zeta$-AID-EGFP mRNA (Fig. 2B-D). In these groups, the 2-cell rates were higher than the activation rates, as observed in the group of $10^{-2} \mathrm{ng} / \mu \mathrm{hPLC} \zeta$ mRNA injection above (Fig. 1B, C). However, $82-100 \%$ of oocytes were activated upon injection of $\geq 10^{-1} \mathrm{ng} / \mu \mathrm{l} \mathrm{hPLC} \zeta$-AID-EGFP mRNA and those injected with $10^{-1} \mathrm{ng} / \mu \mathrm{l}$ showed a significantly higher blastocyst formation rate $(69 \%)$ than that of other groups. Oocytes injected with higher concentrations of mRNA $\left(10^{1}\right.$ and $\left.10^{2} \mathrm{ng} / \mu \mathrm{l}\right)$ arrested before the blastocyst stage. These results indicate that neither fusion of hPLC $\zeta$ with AID and EGFP, nor coinjection with OsTIR1 mRNA affected the activity of the $\mathrm{hPLC} \zeta$ protein.

\section{EGFP monitoring for auxin-induced degradation of $h P L C \zeta$ - AID-EGFP in mouse oocytes}

Next, we tested whether the degradation of hPLC $\zeta$-AID-EGFP in the mRNA-injected oocytes could be induced by auxin using EGFP fluorescence as an indicator, according a method previously reported (Fig. 3A) [18, 25]. We used purified IAA to induce AID degradation $[18,25]$. In the absence of IAA, the EGFP fluorescence level in the injected oocytes increased with time and plateaued at around $4 \mathrm{~h}$ after mRNA injection (Fig. 3B, C). The EGFP signal was detected in the cytoplasm (Fig. 3B), consistent with a previous report [15]. In contrast, treatment of the mRNA-injected oocytes with IAA greatly reduced the EGFP signals, although slight EGFP signals continued to be detectable until at least $8 \mathrm{~h}$ after injection. Noninjected control oocytes activated with strontium chloride did not show any EGFP fluorescence. These data suggest that the $\mathrm{hPLC} \zeta$-AID-EGFP protein can be degraded efficiently by auxin treatment in mouse oocytes.

\section{Auxin treatment improved the development rate of oocytes injected with high concentrations of $h P L C \zeta-A I D-E G F P$ $m R N A$}

To examine the biological consequences of auxin-induced degradation of hPLC $\zeta$-AID-EGFP protein, we cultured the mRNA-injected oocytes with or without IAA and observed their subsequent embryonic development until the blastocyst stage. We first confirmed that IAA treatment does not affect the development of oocytes activated by strontium chloride (Fig. 4A-C). When oocytes were activated with $10^{-1} \mathrm{ng} / \mu \mathrm{l} \mathrm{hPLC} \zeta$-AID-EGFP mRNA, IAA treatment significantly reduced the rates of oocyte activation and development into 2-cells and blastocysts (Fig. 4). The oocytes injected with $10^{\circ} \mathrm{ng} / \mu \mathrm{l}$ fused mRNA and cultured with IAA also showed a significantly reduced activation rate from $100 \%$ to $90 \%$ (Fig. 4A). However, after in vitro culture, they developed into blastocysts at a rate of $69 \%$, which was significantly higher than that of the non-IAA controls (43\%; Fig. 4C and D). This was also the case with oocytes injected with $10^{1} \mathrm{ng} /$ $\mu \mathrm{l}$ fused mRNA; the 2-cell and blastocyst rates were significantly improved by IAA treatment (96\% and 64\%, respectively; Fig. 4C and D).

Full-term development of embryos generated by ROSI using oocytes activated with $h P L C \zeta$-AID-EGFP and cultured with IAA

Finally, to examine the feasibility of using this hPLC $\zeta$-AID system for assisted fertilization, we performed ROSI coupled with hPLC $\zeta$ AID-mediated oocyte activation and observed postimplantation development following embryo transfer. We microinjected mRNAs for hPLC $\zeta$-AID-EGFP $\left(10^{0} \mathrm{ng} / \mu \mathrm{l}\right)$ and OsTIR1 to oocytes and treated them with IAA for $3-5 \mathrm{~h}$. We performed ROSI using the oocytes that had proceeded to telophase II with extrusion of the second 
A

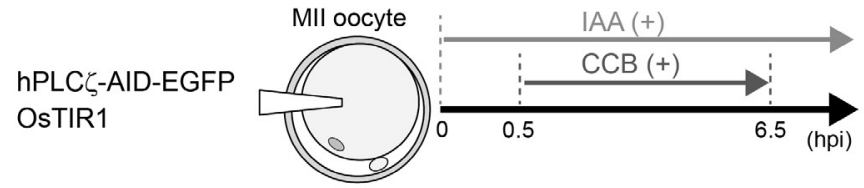

B

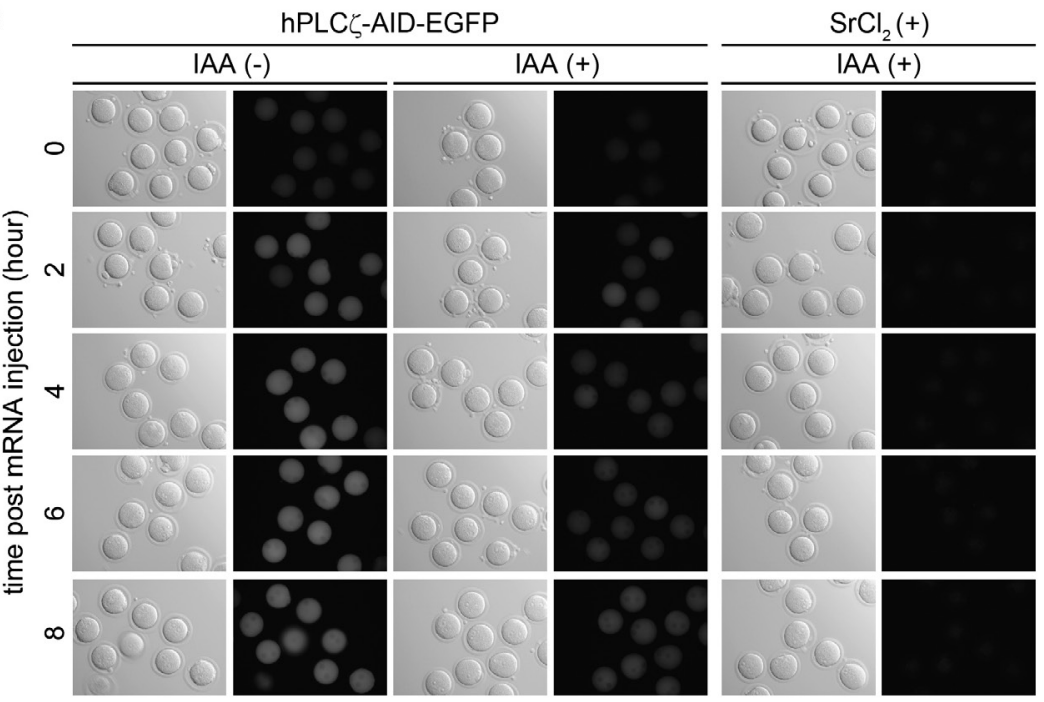

C

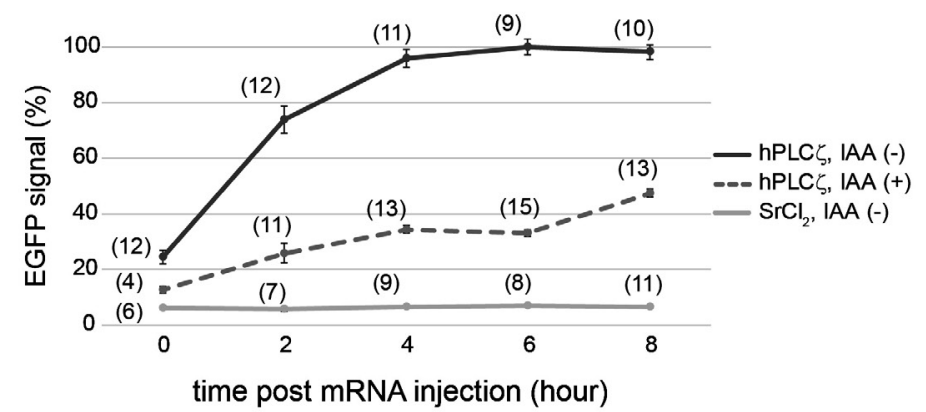

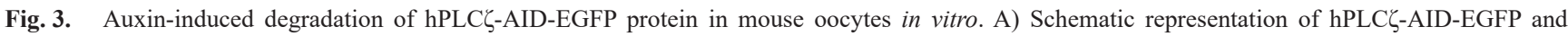
OsTIR1 mRNA injections into MII oocytes and their culture with CCB from 0.5-6.5 hpi and with IAA from 0-8 hpi. B) Microscopic observations over time of EGFP fluorescence in oocytes injected with $10^{2} \mathrm{ng} / \mu \mathrm{l}$ hPLC $\zeta$-AID-EGFP and $1000 \mathrm{ng} / \mu \mathrm{l} \mathrm{OsTIR1} \mathrm{mRNAs} \mathrm{and} \mathrm{cultured} \mathrm{with} \mathrm{or}$ without IAA [IAA $(+)$ or IAA $(-)]$. The concentration of hPLC $\zeta$-AID-EGFP mRNA was higher than the optimal concentration for oocyte activation to detect the changes of the EGFP signal intensity. (C) EGFP signal intensities in oocytes injected with hPLCל-AID-EGFP and OsTIR1 mRNAs and cultured with or without IAA. $\mathrm{SrCl}_{2}(+)$, oocytes activated with strontium chloride. The numbers in parentheses indicate the number of oocytes examined at each stage. The intensity level of the hPLC $\zeta$, IAA (-) group at 6 hpi was set as $100 \%$ on the y-axis because it showed the highest level of EGFP intensity among the experimental groups.

polar body (Fig. 5A). Most (86\%) of the oocytes surviving ROSI developed to the 2-cell stage on the following day (Fig. 5B). After transfer of these 2-cell embryos into pseudopregnant female mice, $53 \%(30 / 57)$ were implanted and 36\% (24/57; 11 males and 13 females) developed into normal offspring at day 19.5 (Fig. 5B, C). These data suggest that this hPLC $\zeta$-AID system could be applied practically for assisted fertilization in mammals.

\section{Discussion}

Here, we showed that although hPLC $\zeta$ mRNA injection can efficiently induce activation in mouse oocytes, subsequent embryonic development is impaired by excessive accumulation of the hPLC $\zeta$ protein in the oocytes, for unknown reasons (Figs. 1,2). We employed the AID technology to facilitate degradation of the excess hPLC $\zeta$ protein and confirmed its efficacy by the significant improvement in development of embryos injected with high concentrations of hPLC $\zeta$ mRNA (Figs. 3, 4). We also demonstrated that this hPLC $\zeta$-AID strategy could be applied to ROSI to produce pups (Fig. 5).

The AID technology, harnessing an auxin-dependent protein degradation system originally found in plants, has been applied to a wide variety of cell types from many different species, including mammals [18, 25]. AID-mediated degradation requires the SCF E3 ubiquitin ligase, which functions together with OsTIR. We show 

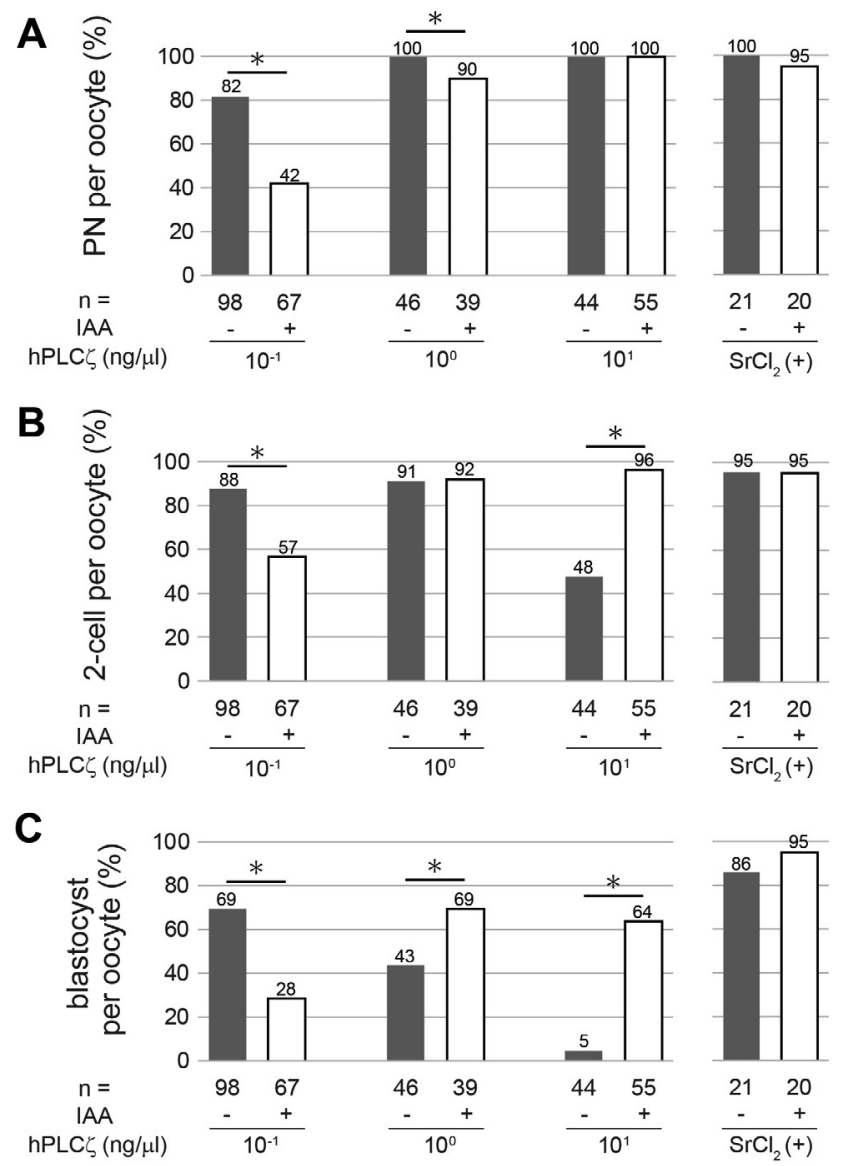

D

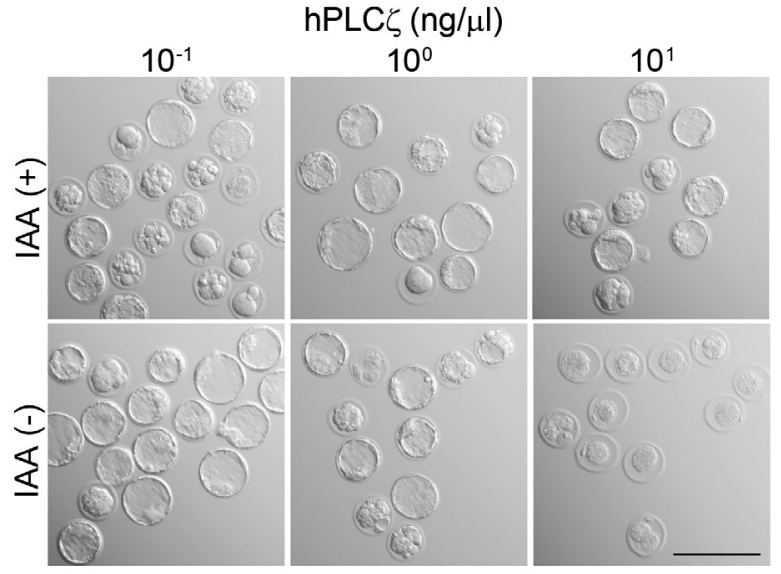

Fig. 4. Activation and development rates of mouse oocytes injected with hPLCל-AID-EGFP and cultured with IAA. A-C) Rates of 2-PN (6.5 hpi), 2-cell (24 hpi), and blastocyst (96 hpi) formation per oocytes that survived at $6.5 \mathrm{hpi}$. Oocytes were injected with $10^{-1}$ $10^{1} \mathrm{ng} / \mu \mathrm{l} \mathrm{hPLC} \zeta$-AID-EGFP and $1000 \mathrm{ng} / \mu \mathrm{l}$ OsTIR1 mRNAs and cultured with CCB (from 0.5-6.5 hpi) and IAA (from 0-96 hpi). $\mathrm{SrCl}_{2}(+)$, oocytes activated with strontium chloride. The data for oocytes cultured without IAA are the same as those in Fig. 2B-D. * P $<0.05$. D) Representative images of blastocysts ( 96 hpi) derived from oocytes injected with hPLC $\zeta$-AID-EGFP and OsTIR1 mRNAs and cultured with or without IAA. Scale bars, $200 \mu \mathrm{m}$
A

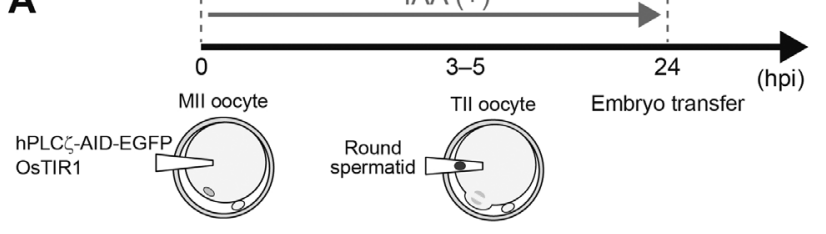

B
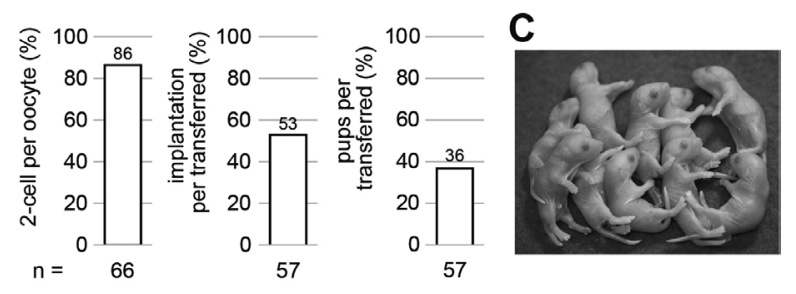

Fig. 5. Round spermatid injection (ROSI) into mouse oocytes injected with hPLC $\zeta$-AID-EGFP mRNA and cultured with IAA. A) Schematic representation of round spermatid injection into mouse telophase II (TII) oocytes injected with $10^{\circ} \mathrm{ng} / \mu \mathrm{l} \mathrm{hPLC} \zeta$-AIDEGFP and $1000 \mathrm{ng} / \mu \mathrm{l}$ OsTIR1 mRNAs and cultured with IAA. B) Two-cell rate (24 hpi) per oocytes that survived just after ROSI, and the implantation and birth rates per 2-cell embryos transferred at $24 \mathrm{hpi}$. C) A litter of newborn offspring produced by ROSI from oocytes activated with hPLCל-AID-EGFP.

here that this AID-mediated degradation works in mouse oocytes as well, suggesting the presence of SCF E3 ligase in mammalian oocytes. However, our EGFP fluorescence monitoring revealed that AID failed to completely abolish the $\mathrm{hPLC} \zeta$ proteins upon auxin treatment (Fig. 3B, C). This is in clear contrast with previous reports showing almost complete depletion of AID-tagged protein by auxin treatment in NIH3T3 and embryonic stem cells $[18,25]$. One potential explanation for this difference is that we introduced PLC $\zeta$ as a form of mRNA, whereas other studies used plasmids or DNA transfection and established stable lines [18, 25, 28-30]. In contrast to DNA/plasmid transfection approaches, where mRNA is transcribed continuously from the inserted DNA fragment by endogenous transcriptional machinery, our mRNA injection method endowed massive copies of mRNA at a single time point so the amount of proteins translated from injected $\mathrm{hPLC} \zeta \mathrm{mRNA}$ might have overcome the degradation ability of the AID system for complete depletion. Alternatively, the SCF E3 ligase in mouse oocytes might be less active than in other cell types. Further optimization of this approach (e.g., injection of AID-tagged protein, coinjection with SCF E3 ligase, and change of the timing of IAA treatment) might allow complete degradation of AID-tagged proteins in mouse oocytes and more efficient embryonic development.

Importantly, we succeeded in obtaining live pups by ROSI coupled with PLC $\zeta$-AID-mediated oocyte activation at relatively high efficiency $(36 \%$; B6D2F1 $\times$ C57BL/6J; Fig. 5). This pup form rate is similar to or even better than those in previous studies obtained via ROSI using electric pulses $(28 \%$; B6D2F $1 \times \mathrm{B} 6 \mathrm{D} 2 \mathrm{~F} 1)[4]$ or strontium chloride $(29 \%$; B6D2F1 $\times$ B6D2F1) [31] for activation of the $\mathrm{B} 6 \mathrm{D} 2 \mathrm{~F} 1$ oocytes as in the present study. Also, this pup rate was higher than that of ROSI with the intact hPLC $\zeta$ mRNA $\left(2 \times 10^{0} \mathrm{ng} /\right.$ $\mu \mathrm{l} ; 16 \%$ per transfer; B6D2F1 $\times$ C57BL/6J or ICR, data not shown). 
Although Nakanishi et al. [32] succeeded in obtaining mouse pups using oocytes activated with a short form of mouse PLC $\zeta$ mRNA, the efficiency was remarkably low (7\% per transfer; B6D2F1 or ICR $\times$ B6D2F1). These facts suggest that, compared with these previous systems, our PLC $\zeta$-AID system has a similar or even better potential for activating mouse oocytes without compromising subsequent developmental capacity.

It is known that the efficiencies of oocyte activation methods differ between species. For example, strontium chloride is one of the most efficient activation methods for mouse oocytes, but electric pulses or calcium ionophores are more often used for porcine and bovine oocytes [33, 34]. Moreover, in some mammals, including the common marmoset, only little information about oocyte activation methods has been reported $[35,36]$. In contrast, because the $\mathrm{Ca}^{2+}$ oscillation-inducing activity of PLC $\zeta$ is conserved among many vertebrates $[10,15], \mathrm{PLC} \zeta$ injection could be widely used for oocyte activation. Therefore, our novel AID method could contribute to promoting the efficiency of the PLC $\zeta$ activation method, advancing the development of mammalian assisted reproductive technology in general.

In summary, we have demonstrated that the AID technology could induce the protein degradation in mammalian oocyte by injecting AID-tagged hPLC $\zeta$ and OsTIR mRNAs. We also showed that the $\mathrm{hPLC} \zeta$ protein translated from high concentrations of injected mRNA inhibited embryonic development, but this could be rescued by degrading the hPLC $\zeta$ protein using our AID technology. With this technology, the embryo development and pup formation rates of hPLC $\zeta$-injected oocytes could be improved in many species of animals.

\section{Acknowledgments}

We thank Dr Azusa Inoue for technical advice about the AID technology. We also thank Toshiko Tomishima for help with maintaining the mouse strains. This research was supported by KAKENHI grants 17H07367 (KM), 15H04854 (JI), and 25112009 (AO), and Brain/MINDS from the Japan Agency for Medical Research and development (AO).

\section{References}

1. Sato Y, Miyazaki S, Shikano T, Mitsuhashi N, Takeuchi H, Mikoshiba K, Kuwabara Y. Adenophostin, a potent agonist of the inositol 1,4,5-trisphosphate receptor, is useful for fertilization of mouse oocytes injected with round spermatids leading to normal offspring. Biol Reprod 1998; 58: 867-873. [Medline] [CrossRef]

2. Ogonuki N, Sankai T, Yagami K, Shikano T, Oda S, Miyazaki S, Ogura A. Activity of a sperm-borne oocyte-activating factor in spermatozoa and spermatogenic cells from cynomolgus monkeys and its localization after oocyte activation. Biol Reprod 2001; 65: 351-357. [Medline] [CrossRef]

3. Parrington J, Davis LC, Galione A, Wessel G. Flipping the switch: how a sperm activates the egg at fertilization. Dev Dyn 2007; 236: 2027-2038. [Medline] [CrossRef]

4. Kimura Y, Yanagimachi R. Mouse oocytes injected with testicular spermatozoa or round spermatids can develop into normal offspring. Development 1995; 121: 2397-2405. [Medline]

5. Ogura A, Matsuda J, Asano T, Suzuki O, Yanagimachi R. Mouse oocytes injected with cryopreserved round spermatids can develop into normal offspring. J Assist Reprod Genet 1996; 13: 431-434. [Medline] [CrossRef]

6. Sasagawa I, Yanagimachi R. Comparison of methods for activating mouse oocytes for spermatid nucleus transfer. Zygote 1996; 4: 269-274. [Medline] [CrossRef]

7. Saunders CM, Larman MG, Parrington J, Cox LJ, Royse J, Blayney LM, Swann K, Lai FA. PLC zeta: a sperm-specific trigger of $\mathrm{Ca}\left({ }^{2+}\right)$ oscillations in eggs and embryo development. Development 2002; 129: 3533-3544. [Medline]

8. Swann K, Lai FA. The sperm phospholipase $\mathrm{C}-\zeta$ and $\mathrm{Ca}^{2+}$ signalling at fertilization in mammals. Biochem Soc Trans 2016; 44: 267-272. [Medline] [CrossRef]

9. Heytens E, Parrington J, Coward K, Young C, Lambrecht S, Yoon SY, Fissore RA, Hamer R, Deane CM, Ruas M, Grasa P, Soleimani R, Cuvelier CA, Gerris J, Dhont M, Deforce D, Leybaert L, De Sutter P. Reduced amounts and abnormal forms of phospholipase C zeta (PLCzeta) in spermatozoa from infertile men. Hum Reprod 2009; 24: 2417-2428. [Medline] [CrossRef]

10. Ito J, Parrington J, Fissore RA. PLC $\zeta$ and its role as a trigger of development in vertebrates. Mol Reprod Dev 2011; 78: 846-853. [Medline] [CrossRef]

11. Kashir J, Jones C, Lee HC, Rietdorf K, Nikiforaki D, Durrans C, Ruas M, Tee ST, Heindryckx B, Galione A, De Sutter P, Fissore RA, Parrington J, Coward K. Loss of activity mutations in phospholipase $\mathrm{C}$ zeta (PLC $\zeta$ ) abolishes calcium oscillatory ability of human recombinant protein in mouse oocytes. Hum Reprod 2011; 26: 3372-3387. [Medline] [CrossRef]

12. Kashir J, Konstantinidis M, Jones C, Lemmon B, Lee HC, Hamer R, Heindryckx B, Deane CM, De Sutter P, Fissore RA, Parrington J, Wells D, Coward K. A maternally inherited autosomal point mutation in human phospholipase $\mathrm{C}$ zeta (PLC $\zeta$ ) leads to male infertility. Hum Reprod 2012; 27: 222-231. [Medline] [CrossRef]

13. Hachem A, Godwin J, Ruas M, Lee HC, Ferrer Buitrago M, Ardestani G, Bassett A, Fox S, Navarrete F, de Sutter P, Heindryckx B, Fissore R, Parrington J. PLC $\zeta$ is the physiological trigger of the $\mathrm{Ca}^{2+}$ oscillations that induce embryogenesis in mammals but conception can occur in its absence. Development 2017; 144: 2914-2924. [Medline] [CrossRef]

14. Nozawa K, Satouh Y, Fujimoto T, Oji A, Ikawa M. Sperm-borne phospholipase C zeta1 ensures monospermic fertilization in mice. Sci Rep 2018; 8: 1315. [Medline] [CrossRef]

15. Ito M, Shikano T, Oda S, Horiguchi T, Tanimoto S, Awaji T, Mitani H, Miyazaki S. Difference in $\mathrm{Ca}^{2+}$ oscillation-inducing activity and nuclear translocation ability of PLCZ1, an egg-activating sperm factor candidate, between mouse, rat, human, and medaka fish. Biol Reprod 2008; 78: 1081-1090. [Medline] [CrossRef]

16. Yoda A, Oda S, Shikano T, Kouchi Z, Awaji T, Shirakawa H, Kinoshita K, Miyazaki S. $\mathrm{Ca}^{2+}$ oscillation-inducing phospholipase $\mathrm{C}$ zeta expressed in mouse eggs is accumulated to the pronucleus during egg activation. Dev Biol 2004; 268: 245-257. [Medline] [CrossRef]

17. Cox LJ, Larman MG, Saunders CM, Hashimoto K, Swann K, Lai FA. Sperm phospholipase Czeta from humans and cynomolgus monkeys triggers $\mathrm{Ca}^{2+}$ oscillations, activation and development of mouse oocytes. Reproduction 2002; 124: 611-623. [Medline] [CrossRef]

18. Nishimura K, Fukagawa T, Takisawa H, Kakimoto T, Kanemaki M. An auxin-based degron system for the rapid depletion of proteins in nonplant cells. Nat Methods 2009; 6: 917-922. [Medline] [CrossRef]

19. Deshaies RJ. SCF and Cullin/Ring H2-based ubiquitin ligases. Annu Rev Cell Dev Biol 1999; 15: 435-467. [Medline] [CrossRef]

20. Chapman EJ, Estelle M. Mechanism of auxin-regulated gene expression in plants. Annu Rev Genet 2009; 43: 265-285. [Medline] [CrossRef]

21. Lambrus BG, Uetake Y, Clutario KM, Daggubati V, Snyder M, Sluder G, Holland AJ. p53 protects against genome instability following centriole duplication failure. $J$ Cell Biol 2015; 210: 63-77. [Medline] [CrossRef]

22. Lawitts JA, Biggers JD. Culture of preimplantation embryos. Methods Enzymol 1993; 225: 153-164. [Medline] [CrossRef]

23. Yamagata K, Yamazaki T, Yamashita M, Hara Y, Ogonuki N, Ogura A. Noninvasive visualization of molecular events in the mammalian zygote. Genesis 2005; 43: 71-79. [Medline] [CrossRef]

24. Kubota T, Nishimura K, Kanemaki MT, Donaldson AD. The Elg1 replication factor C-like complex functions in PCNA unloading during DNA replication. Mol Cell 2013; 50: 273-280. [Medline] [CrossRef]

25. Natsume T, Kiyomitsu T, Saga Y, Kanemaki MT. Rapid protein depletion in human cells by auxin-inducible degron tagging with short homology donors. Cell Reports 2016; 15: 210-218. [Medline] [CrossRef]

26. Ogura A, Yanagimachi R, Usui N. Behaviour of hamster and mouse round spermatid nuclei incorporated into mature oocytes by electrofusion. Zygote 1993; 1: 1-8. [Medline] [CrossRef]

27. Benjamini Y, Hochberg Y. Controlling the false discovery rate - a practical and powerful approach to multiple testing. J R Stat Soc, B 1995; 57: 289-300.

28. Kanke M, Nishimura K, Kanemaki M, Kakimoto T, Takahashi TS, Nakagawa T, Masukata H. Auxin-inducible protein depletion system in fission yeast. BMC Cell Biol 2011; 12: 8. [Medline] [CrossRef]

29. Holland AJ, Fachinetti D, Han JS, Cleveland DW. Inducible, reversible system for the rapid and complete degradation of proteins in mammalian cells. Proc Natl Acad Sci USA 2012; 109: E3350-E3357. [Medline] [CrossRef]

30. Zhang L, Ward JD, Cheng Z, Dernburg AF. The auxin-inducible degradation (AID) system enables versatile conditional protein depletion in C. elegans. Development 2015 
142: 4374-4384. [Medline] [CrossRef]

31. Kishigami S, Wakayama S, Nguyen VT, Wakayama T. Similar time restriction for intracytoplasmic sperm injection and round spermatid injection into activated oocytes for efficient offspring production. Biol Reprod 2004; 70: 1863-1869. [Medline] [CrossRef]

32. Nakanishi T, Ishibashi N, Kubota H, Inoue K, Ogonuki N, Ogura A, Kashiwabara S, Baba T. Birth of normal offspring from mouse eggs activated by a phospholipase Czeta protein lacking three EF-hand domains. $J$ Reprod Dev 2008; 54: 244-249. [Medline] [CrossRef]

33. Miyagawa S, Matsunari H, Watanabe M, Nakano K, Umeyama K, Sakai R, Takayanagi S, Takeishi T, Fukuda T, Yashima S, Maeda A, Eguchi H, Okuyama H, Nagaya M, Nagashima H. Generation of $\alpha 1,3$-galactosyltransferase and cytidine monophospho$\mathrm{N}$-acetylneuraminic acid hydroxylase gene double-knockout pigs. J Reprod Dev 2015; 61:
449-457. [Medline] [CrossRef]

34. De Bem THC, da Silveira JC, Sampaio RV, Sangalli JR, Oliveira MLF, Ferreira RM, Silva LA, Perecin F, King WA, Meirelles FV, Ramos ES. Low levels of exosomalmiRNAs in maternal blood are associated with early pregnancy loss in cloned cattle. Sci Rep 2017; 7: 14319. [Medline] [CrossRef]

35. Marshall VS, Wilton LJ, Moore HD. Parthenogenetic activation of marmoset (Callithrix jacchus) oocytes and the development of marmoset parthenogenones in vitro and in vivo. Biol Reprod 1998; 59: 1491-1497. [Medline] [CrossRef]

36. Sotomaru Y, Hirakawa R, Shimada A, Shiozawa S, Sugawara A, Oiwa R, Nobukiyo A, Okano H, Tamaoki N, Nomura T, Hiyama E, Sasaki E. Preimplantation development of somatic cell cloned embryos in the common marmoset (Callithrix jacchus). Cloning Stem Cells 2009; 11: 575-583. [Medline] [CrossRef] 